\title{
Earnings Management and Myopic Marketing Management: Differential Metrics and Emphases
}

\section{Inho Suk*}

School of Management, State University of New York at Buffalo, Buffalo, NY 14260, USA

This article discusses the relation and differences between earnings management in the accounting literature and myopic marketing management in the marketing literature and suggests several new steps to reduce managers' incentives for earnings management or myopic marketing management. Agency theory contends that the presence of information asymmetry between the principal and the agent and the costs of obtaining information make it difficult for the principal to monitor the agent [1]. As an agent, the firm manager manipulates the earnings number by temporarily inflating it for his self interest in various ways. It is well established in the literature that earnings management has negative implications for firm value in the long run.

The accounting literature documents that two of the most common ways to manipulate earnings are accruals management and real activities management (e.g., Roychowdhury [2], Cohen et al. [3], Cohen and Zarowin [4]). Cohen et al. [3] found that real activities management has become an increasingly popular tool for manipulating short-term earnings after the Sarbanes-Oxley Act of 2002. Roychowdhury [2] defines real activities management and considers the abnormal levels of cash flow from operations, production costs, and discretionary expenditures as the measures for real activities management. The three manipulation methods are: (1) acceleration of the timing of sales through increased price discounts or more lenient credit terms, which will boost current period earnings but lower current period cash flows, (2) reporting lower cost of goods sold through increased production, which will increase operating margin but lower cash flows and increases production costs, and (3) reducing discretionary expenditures that include advertising, research and development (R\&D), and sales, general and administrative expenses, which will increase earnings. The accounting literature measures three abnormal real activities measures as residuals from regressions of real activities variables on sales level and change. Cohen and Zarowin [4] also use two comprehensive metrics of real earnings management activities by combining the three measures.

The marketing literature focuses on the third real activities management measure with a special Emphases on marketing spending (e.g., advertising, sales force, promotional spending) and research and development, which is defined as myopic management in the marketing literature (e.g., Mizik and Jacobson [5], Mizik [6], Chapman and Steenburgh [7], Park et al. [8]). This myopic behavior of temporarily reducing such marketing expenditures will boost the current period earnings but significantly impairs the value relevance of marketing functions. Unlike the accounting literature, the marketing literature measures the abnormal level of marketing spending as residuals of regression of the current period marketing spending on the previous period marketing and time and industry dummies, rather than sales level and change (e.g., Mizik [6]). Because marketing expenditures generally have carryover effects on sales, marketing researchers may tend to use the previous period marketing expenditures, rather than sales level and change, in estimating the abnormal level of marketing spending. Further, marketing assets are primarily be sacrificed in manipulating earnings since they are not directly related to production, which may lead marketing researchers to use the previous period marketing spending in calculating the abnormal marketing spending.

Although the gap between marketing metrics and accounting measures is decreasing, it is still not trivial. The accounting literature (e.g., Burgstahler and Dichev [9], DeGeorge et al. [10], Kross et al. [11]) uses three earnings benchmarks: zero earnings, prior period earnings, and analysts' earnings forecast consensus and shows a firm's tendency to report small profits, small earnings increases over last year, and small earnings surprises over analysts' earnings forecasts. It suggests that firms manage discretionary accruals, earnings expectations, and real activities to beat these earnings benchmarks (e.g., Cheng and Warfield [12], Roychowdhury [2], Kross et al [11]). Rather than focusing on these three benchmarks, however, the marketing literature focuses on identifying myopic firms, which are defined when the abnormal level of earnings is positive and abnormal levels of marketing spending are negative. Similar to abnormal levels of marketing spending measures, the abnormal level of earnings is calculated as residuals of regression of the current period earnings on the previous period earnings and time and industry dummies. This suggests that marketing researchers particularly emphasize the effect of negative abnormal marketing and $\mathrm{R} \& \mathrm{D}$ spending on posive abnormal earnings.

Real activities management or myopic management has a longterm net negative impact on firm value. Prior studies attribute the negative financial performance of various corporate behaviors to the real activities management or myopic marketing management. For example, Mizik and Jacobson [5] suggest that inferior stock market performance following the seasoned equity offerring (SEO) is due to myopic marketing management. Cohen and Zarowin [4] also find that real activities management leads to negative post-SEO earnings performance. Park et al. [8] find that the target firm's myopic marketing and research and development $(\mathrm{R} \& \mathrm{D})$ budget decisions contribute to the acquirer's inferior post-acquisition returns when the acquisition is paid by cash rather than by stock. There has been a strong demand for the improvement of the share value relevance of marketing metrics and accounting information. How financial reporting of accounting items is relevant to market value has been a longstanding topic for accounting researchers. With concerns over marketing's decreasing influence on corporate policies, marketing researchers have examined interactions between financial performance in the capital market and marketing activities in the product market. I argue that reducing managers'

${ }^{*}$ Corresponding author: Inho Suk, School of Management, State University of New York at Buffalo, 342 Jacobs Management Center Buffalo, NY 14260, USA, E-mail: inhosuk@buffalo.edu

Received July 28, 2013; Accepted July 29, 2013; Published August 03, 2013

Citation: Suk I (2013) Earnings Management and Myopic Marketing Management: Differential Metrics and Emphases. J Account Mark 2: e120. doi: 10.4172/2168$9601.1000 \mathrm{e} 120$

Copyright: (c) 2013 Suk I. This is an open-access article distributed under the terms of the Creative Commons Attribution License, which permits unrestricted use, distribution, and reproduction in any medium, provided the original author and source are credited. 
Citation: Suk I (2013) Earnings Management and Myopic Marketing Management: Differential Metrics and Emphases. J Account Mark 2: e120. doi: 10.4172/2168-9601.1000e120

real earnings management, such as myopic marketing management, should be a remedy to improve both the value relevance of accounting information or the marketing influence on financial performance in the capital market.

The finance and accounting literatures suggest that increases in executive equity compensation and voluntary information disclosure diminish real earnings or myopic marketing management. Since a firm's corporate-level strategy is largely driven by the top management team (TMT), which generally includes chief executive officer (CEO), chief financial officer (CFO), and chief marketing officer (CMO), recent marketing sudies by Suk [13], Park [14], and Park et al. [15] emphasize the role of the CMO. They argue that, if the CMO is a member of TMT, receives a substantial portion of his compensation as equity, and is given a reasonably long tenure, he can help deter the near-term focused behaviors if he pursues firm-value maximization in the long term sense, rather than just looks for a short-term increase in sales or earnings, consequently increasing the value relevance of marketing and accounting functions. Kwak et al. [16] suggest that including chief legal officer (CLO) generally referred as general counsel, increases the quality of financial reporting through its voluntary governance mechanism. If this is the case, another way to reduce earnings management, including myopic marketing management, is to include the CLO on TMT, which will ultimately enhance the value relevance of marketing metrics and accounting information.

\section{References}

1. Jensen MC, Meckling WM (1976) Theory of the firm: Managerial behavior agency costs and ownership structure. Journal of Financial Economics 3: 305-360.

2. Roychowdhury S (2006) Earnings management through real activities manipulation. Journal of Accounting and Economics 42: 335-370.

3. Cohen DA, Dey A, Lys T (2008) Real and accrual-based earnings management in the pre- and post-Sarbanes-Oxley periods. The Accounting Review 83: 757-787.
4. Cohen DA, Zarowin P (2010) Accrual-based and real earnings management activities around seasoned equity offerings. Journal of Accounting and Economics 50: 2-19.

5. Mizik N, Jacobson R (2007) Myopic marketing mangement: Evidence of the phenomenon and its longterm performance consequences in the SEO context. Marketing Science 26: 361-379.

6. Mizik N (2010) The theory and practice of myopic mangement. Journal of Marketing Research 47: 594-611.

7. Chapman CJ, Steenburgh, TJ (2011) An investigation of earnings management through marketing actions. Management Science. 57: 72-92.

8. Park K, Kalwani M, Suk I (2013) The detrimental role of myopic marketing management in value creation of mergers and acquisitions. Working paper. Purdue University and SUNY at Buffalo.

9. Burgstahler D, Dichev ID (1997) Earnings management to avoid earnings decreases and losses. Journal of Accounting and Economics 24: 99-126.

10. Degeorge F, Patel J, Zeckhauser R (1999) Earnings Management to Exceed Thresholds. Journal of Business 72: 1-33.

11. Kross WJ, Ro BT, Suk I (2011) Consistency in meeting or beating the market's expectations and management earnings forecasts. Journal of Accounting and Economics 51: 37-57.

12. Cheng Q, Warfield TD (2005) Equity incentives and earnings management. The Accounting Review 80: 441-476.

13. Suk I (2012) Marketing-Accounting-Finance interface: The role of chief marketing officer. Journal of Accounting and marketing 2: 1-2.

14. Park K (2013) Top management composition with chief marketing officer and the effectiveness of marketing decisions. Working paper. Purdue University.

15. Park K, Chintagunta P, Suk I (2013) The differential performance consequences of chief marketing officer equity-based compensation: chief marketing office versus other executives in top management. Working paper. Purdue University, University of Chicago, and SUNY at Buffalo.

16. Kwak B, Ro BT, Suk I (2012) The Composition of Top Management with General Counsel and Voluntary Information Disclosure. Journal of Accounting and Economics 54: 19-41. 